\title{
THE IN VITRO INACTIVATION OF PITRESSIN BY NORMAL AND CIRRHOTIC HUMAN LIVER ${ }^{1}$
}

\author{
By GEORGE E. MILLER ANd CHARLES E. TOWNSEND ${ }^{2}$ wITH THE TECH NICAL \\ ASSISTANCE OF MARY CLAIRE JONES
}

(From the Departments of Medicine of the University of Buffalo School of Medicine and the Buffalo General Hospital, Buffalo, N. Y.)

(Submitted for publication October 22, 1953; accepted December 16, 1953)

A generally acceptable explanation of the mechanism responsible for the formation of ascites and peripheral edema in the patient with hepatic cirrhosis has yet to be formulated. Reduction in serum oncotic pressure, portal hypertension, and distortion of sodium metabolism have each had their champions and their detractors. A prominent current controversy concerns the role of antidiuretic hormone in the pathogenesis of this fluid retention.

It has been demonstrated that hepatic tissue is capable of inactivating antidiuretic hormone both in vitro and in vivo $(1,2)$. The available evidence suggests that this is accomplished by the activity of an enzyme system whose maximal effectiveness is limited to a narrow range of temperature and $\mathrm{pH}$ (1-3). The presence of an antidiuretic material in the urine and serum of patients with fluid retention and cirrhosis (4-6) has suggested to several workers that an impairment of the hepatic inactivation of antidiuretic hormone may play an important role in producing the accumulation of ascites and peripheral edema in this disease. The frequent observation of oliguria and the reported delay in onset of diuresis following a water load (7-9) in such patients has been interpreted as additional evidence to support this point of view.

Recently, all of these observations have been challenged. When the dog, rather than the rat was used for assay, Van Dyke, Ames, and Plough (10) were unable to confirm the presence of significant antidiuretic activity in the urine of cirrhotic patients. Other workers $(11,12)$ have been unable to demonstrate any delay in diuresis following a water load, any increased sensitivity to, or

\footnotetext{
1 Studies reported here were supported in part by grants from the Western New York State Heart Association and the Junior Board of the Buffalo General Hospital.

2 Present Address: 701 West Valley Blvd., Alhambra, California.
}

prolonged effectiveness of, physiologic amounts of Pitressin in the subject with cirrhosis who is actively retaining fluid.

In view of these discrepancies it seemed appropriate to investigate directly the capacity of cirrhotic human liver to inactivate antidiuretic hormone. Before this could be determined it was necessary to learn whether the in vitro hepatic inactivation of Pitressin could be demonstrated when the dog, rather than the rat, was used for assay, and whether normal human liver was comparable to rat liver in this regard. The results of studies designed to provide answers to these questions comprise the body of this report.

\section{METHODS AND MATERIALS}

Two trained unanesthetized dogs, loaded with 40 to 50 cc. warm tap water per kilogram body weight 90 and 30 minutes prior to an experimental procedure, were used for assay of antidiuretic activity throughout this study. A positive water balance of at least $500 \mathrm{cc}$. was maintained by further intubation and administration of water as required. Urine was collected by indwelling catheter for five-minute periods with an air wash at the conclusion of each period to insure complete collection. Test substances were administered intravenously through an indwelling needle whose patency was maintained by a slow infusion of 5 per cent invert sugar in water.

Liver used in preparing a cell-free homogenate was of three types: rat liver, normal, and cirrhotic human liver. Rat liver was obtained from adult Sprague-Dawley rats immediately after sudden traumatic death. Normal human liver was obtained at abdominal laparotomy performed for some extra-hepatic disease. Cirrhotic human liver ${ }^{3}$ was obtained during abdominal laparotomy for a

${ }^{3}$ We are deeply grateful to the Department of Surgery of the Buffalo General Hospital for providing us with specimens of normal human liver and to Dr. David Habif of the Department of Surgery, Presbyterian Hospital, New York City for providing most of the specimens of cirrhotic liver tissue. Without such generous cooperation this study would not have been possible. Dr. John Sheffer of the Department of Pathology, Buffalo General Hospital, very kindly examined the sections of cirrhotic liver tissue. 
portalsystemic venous shunt (For case abstracts, see Appendix). With a single exception in each instance, rat and normal human liver were processed immediately. These samples and all specimens of cirrhotic liver were immediately frozen in carbon dioxide and stored in the frozen state until they were subjected to study.

A liver homogenate was prepared by grinding the tissue with sea sand in isotonic saline according to the method of Eversole, Birnie, and Gaunt (2). The homogenate was centrifuged and the supernatant fluid adjusted to $\mathrm{pH} 6.8$ with phosphate buffer. An aliquot of this supernatant, representing $100 \mathrm{mg}$. of liver tissue, was then incubated with 90 to 100 milliunits of Pitressin at $37^{\circ} \mathrm{C}$. for 30 minutes. One $\mathrm{ml}$. of this mixture, equivalent to 16 mg. of liver tissue and 14 to 16 milliunits of Pitressin, was injected intravenously. An aliquot of the supernatant was incubated without Pitressin to serve as a control. The effect of incubation upon Pitressin alone was also determined.

Antidiuretic activity was calculated from urine volume during the second collection period after administration of a test substance expressed as per cent of the control rate of flow. By this method activity of unknown material was compared with the activity of known amounts of Pitressin. Duration of antidiuresis was not considered since at the low levels of activity studied, this method compared favorably with more complicated calculations employing different parameters.

\section{RESULTS}

The response of an assay animal to graded doses of commercial Pitressin is indicated in Figure 1. Preliminary incubation of Pitressin did not alter this pattern. In a series of experiments the mean reduction in urine flow following one and two milliunit doses of Pitressin is shown in Table $I$. The apparent difference in sensitivity between the two animals is an artefact which results from recording dosage as total amount administered rather than milliunits per kilogram.

The data accumulated in the study of rat liver are summarized in Table II. Inactivation of Pit-

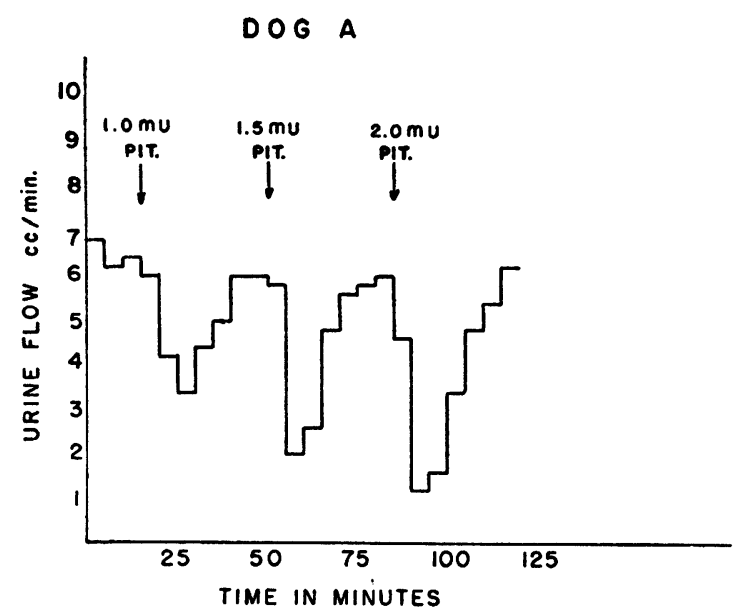

Fig. 1. Antidiuretic Response to Graded Doses of Pitressin (Normal, Water Loaded Dog)

ressin in a range of 0.91 to $1.0 \mathrm{mU}$ per $\mathrm{mg}$. liver tissue, with a mean value of $0.97 \mathrm{mU}$ per $\mathrm{mg}$., is essentially the same as that found by other workers using different assay methods.

Data relating to the studies of normal and cirrhotic human liver are presented in Table III. In ten studies on five specimens of normal tissue the range of inactivation was again 0.9 to $1.0 \mathrm{mU}$ per mg. Since $0.9 \mathrm{mU}$ per $\mathrm{mg}$., was the largest amount

TABLE I

Mean antidiuretic response to Pitressin *

\begin{tabular}{lcr}
\hline \multicolumn{3}{c}{$\begin{array}{c}\text { Alteration in urine flow } \\
\text { (expressed as per cent of control rate) } \\
\text { following Pitressin }\end{array}$} \\
\hline Amount & $1.0 m U$ & $2.0 m U$ \\
Dog A & $-43(36)$ & $-72(4)$ \\
Dog B & $-25(13)$ & $-43(4)$
\end{tabular}

* Number of experiments from which mean was derived is indicated parenthetically. Standard deviation for $1.0 \mathrm{mU}$ amounts: $A-10.1, B-7.4$.

TABLE II

Effect of rat liver homogenate upon the antidiuretic effect of Pitressin *

\begin{tabular}{|c|c|c|c|c|c|c|}
\hline $\begin{array}{l}\text { Aceay } \\
\text { Animal }\end{array}$ & $\begin{array}{l}\text { No. of } \\
\text { studies }\end{array}$ & $\begin{array}{l}\text { Pitresuin } \\
\text { Alded } \\
\text { mil/100 ms. }\end{array}$ & $\begin{array}{l}\text { Pitressin Orighanlly } \\
\text { Presont ig } \\
1.0 \mathrm{ml} \text { Teated } \\
\text { mu }\end{array}$ & $\begin{array}{l}\text { XXanange in } \\
\text { Urine Fion }\end{array}$ & $\begin{array}{l}\text { Aatidiaretic } \\
\text { Activity } \\
\text { Present } \\
\text { mo }\end{array}$ & $\begin{array}{l}\text { Amount } \\
\text { Pittreasia } \\
\text { thactivated } \\
\text { velpheo met. }\end{array}$ \\
\hline A & 15 & 100 & 16 & -25 & 0.5 & 97 \\
\hline B & 1 & 100 & 16 & -5 & 0 & 100 \\
\hline $\bar{A}$ & $\overline{2}$ & 90 & 14.4 & 72 & 0 & 90 \\
\hline B & 3 & 90 & 14.4 & +1 & 0 & 90 \\
\hline
\end{tabular}

* See Methods for details of assay and calculation. 
TABLE III

Effect of human liver homogenate upon the antidiuretic effect of Pitressin *

\begin{tabular}{|c|c|c|c|c|c|c|c|}
\hline Date & Subject & $\begin{array}{l}\text { Assay } \\
\text { Animal }\end{array}$ & $\begin{array}{l}\text { Pitressin } \\
\text { Added } \\
\mathrm{mU} / 100 \mathrm{mg} \text {. }\end{array}$ & $\begin{array}{l}\text { Pitressin } \\
\text { Originally } \\
\text { Present In } \\
1.0 \mathrm{ml} \text { Tested }\end{array}$ & $\begin{array}{l}\text { \% Change In } \\
\text { Urine Flow }\end{array}$ & $\begin{array}{l}\text { Antidiuretic } \\
\text { Activity } \\
\text { Present } \\
\text { mU }\end{array}$ & $\begin{array}{l}\text { Amount } \\
\text { Pitressin } \\
\text { Inactivated } \\
\text { mU/100 mg. }\end{array}$ \\
\hline $11 / 12 / 52$ & $\mathrm{MCCU}$ & $\mathbf{A}$ & $\begin{array}{l}100 \\
100\end{array}$ & $\begin{array}{l}\text { RMAL LIVE } \\
16 \\
16\end{array}$ & $\begin{array}{l}+\quad 6 \\
-50\end{array}$ & $\begin{array}{l}0 \\
1.0\end{array}$ & $\begin{array}{r}100 \\
94\end{array}$ \\
\hline $11 / 19 / 52$ & ELLI & A & $\begin{array}{r}100 \\
100 \\
90\end{array}$ & $\begin{array}{l}16 \\
16 \\
14.4\end{array}$ & $\begin{array}{l}-65 \\
-\quad 56 \\
-\quad 3\end{array}$ & $\begin{array}{l}1.5 \\
1.25 \\
0\end{array}$ & $\begin{array}{l}91 \\
92 \\
90\end{array}$ \\
\hline $11 / 26 / 52$ & GREI & $\mathbf{A}$ & $\begin{array}{r}100 \\
90\end{array}$ & $\begin{array}{l}16 \\
14.4\end{array}$ & $\begin{array}{l}-5 \\
+\quad 6\end{array}$ & $\begin{array}{l}0 \\
0\end{array}$ & $\begin{array}{r}100 \\
90\end{array}$ \\
\hline $12 / 5 / 52$ & IR IS & $\mathbf{B}$ & $\begin{array}{r}100 \\
90\end{array}$ & $\begin{array}{l}16 \\
14.4\end{array}$ & $\begin{array}{r}1 \\
0\end{array}$ & $\begin{array}{l}0 \\
0\end{array}$ & $\begin{array}{r}100 \\
90\end{array}$ \\
\hline $12 / 16 / 52$ & IZYD & B & 90 & 14.4 & +1 & 0 & 90 \\
\hline $1 / 5 / 53$ & CRAN & A & 90 & $\begin{array}{l}\text { RHOTIC LIVE } \\
14.4\end{array}$ & -7 & 0 & 90 \\
\hline $5 / 22 / 53$ & TIBB & $\mathbf{A}$ & 90 & 14.4 & -13 & 0.25 & 88 \\
\hline $6 / 5 / 53$ & TIBB & A & 90 & 14.4 & 0 & 0 & 90 \\
\hline $5 / 22 / 53$ & CHEF & $\mathbf{A}$ & 90 & 14.4 & +6 & 0 & 90 \\
\hline $6 / 5 / 53$ & CHEF & $\mathbf{A}$ & 90 & 14.4 & +7 & 0 & 90 \\
\hline $5 / 25 / 53$ & PFEI & $\mathbf{A}$ & 90 & 14.4 & -99 & $?$ & $?$ \\
\hline $6 / 5 / 53$ & PFEI & A & 90 & 14.4 & -12 & 0.25 & 88 \\
\hline $5 / 25 / 53$ & BECK & $\mathbf{A}$ & 90 & 14.4 & $=7$ & 0 & 90 \\
\hline $5 / 25 / 53$ & LUST & $A$ & 90 & 14.4 & +11 & 0 & 90 \\
\hline
\end{tabular}

* See Methods for details of assay and calculation.

regularly inactivated by the normal liver homogenate, larger quantities were not tested with cirrhotic tissue.

Six specimens of cirrhotic liver provided the material for nine studies. On six occasions, 0.9 $\mathrm{mU}$ Pitressin per mg. liver was completely inactivated, while in two instances 0.88 milliunit was inactivated. The single exception to this pattern which is not significantly different from the normal occurred in the first PFEI assay. In this study the antidiuretic activity remaining after incubation was immeasurably large. Since this result was not confirmed by a subsequent assay, the observation stands unexplained.

During the six-month interval between the study of normal liver and that of cirrhotic liver tissue there was no significant change in the responsiveness of assay animal $A$ to Pitressin. In the earlier period the mean reduction in urine flow following one milliunit amounts of Pitressin was 41.3 per cent (S.D. 8.8) and in the later period 44.5 per cent (S.D. 12.4).

In these studies there was nothing to suggest that freezing affected the inactivating capacity of the rat or human liver. The inactivating principle is apparently stable at low temperatures even without freezing. One specimen, not included here, which was inadvertently allowed to dry in the cold, quantitatively maintained its ability to inactivate Pitressin over a period of three months.

\section{DISCUSSION}

Neutralization of the antidiuretic effect of Pitressin by rat liver homogenate, as observed here, is simple confirmation of earlier work by other investigators $(1,2)$. The use of a different as- 
say' method, however, makes it clear that the rat and dog respond to this experimental situation in a quantitatively similar manner. The extension of the observations to normal human liver also provides direct evidence of the quantitative similarity of hepatic enzymatic inactivation of Pitressin by different species.

Most interesting, however, is the failure to demonstrate a significant difference between nor$\mathrm{mal}$ and cirrhotic human liver in this regard. Such a finding lends support to those who have concluded from other lines of evidence that there is no impairment in the handling of exogenous or endogenous antidiuretic hormone by the patient with cirrhosis $(11,12)$. It does not, on the other hand, elucidate the observations of increased urinary excretion, and serum concentration, of antidiuretic substances in this disease. Nor does it contribute to an understanding of the hypotonicity of body fluid in the patient who is accumulating ascites or peripheral edema, an observation which has been interpreted as a link in a chain of evidence suggesting a primary defect of water metabolism in such a syndrome $(13,14)$.

With these discrepancies in mind it is not unreasonable to question the adequacy of the assay method used here. In our hands the water loaded dog can be used with precision only for the detection of antidiuretic activity equivalent to, or greater than, $0.5 \mathrm{mU}$ Pitressin. Under these circumstances small differences of Pitressin inactivation by normal and diseased liver might easily be missed. In this study the lowest values of inactivation, 88 $\mathrm{mU}$ per $100 \mathrm{mg}$., were found in cirrhotic liver. The question naturally arises whether this represents a real difference which could be established with certainty only by more sensitive and precise methods. Despite this question, which cannot at the moment be answered, the fact is inescapable that even inactivation of $88 \mathrm{mU}$ per $100 \mathrm{mg}$., if extrapolated to a whole liver of 1000 grams means inactivation of $880,000 \mathrm{mU}$ at $37^{\circ}$ in thirty minutes. This is so far in excess of the physiologic needs of the intact organism that it seems highly unlikely that a difference of this magnitude could have any perceptible effect upon water metabolism in this disease.

At the same time such evidence cannot be assumed to deny an abnormality of the hormonal control of water metabolism under these circum- stances; it merely suggests that there is no impairment in hepatic destruction of antidiuretic substance. It is still possible that increased production of antidiuretic hormone by the posterior pituitary may occur in this disease. One such mechanism has been suggested by investigators (15) who demonstrated increased quantities of the hepatic vasodepressor material ferritin, in the serum of patients suffering from cirrhosis and fluid retention as well as in patients with edema of other etiologies. The antidiuretic effect of ferritin is mediated by the neurohypophysis. This study can neither support nor refute such a possibility.

\section{SUMMARY}

1. Utilizing trained, water loaded dogs for assay of antidiuretic activity the inactivation of $1 \mathrm{mU}$ Pitressin per mg. rat liver, as determined by other methods, was confirmed.

2. Normal human liver was not found to be significantly different from rat liver in its capacity to inactivate Pitressin in vitro.

3. Under the conditions of this study no significant difference could be detected between the ability of normal and cirrhotic human liver to inactivate Pitressin.

4. It seems unlikely that impairment in hepatic inactivation of antidiuretic hormone contributes to the accumulation of ascites and peripheral edema in hepatic cirrhosis.

\section{APPENDIX}

$C R A N$ (BGH 228452) : A 57-year old white, alcoholic female with an eight month history of anorexia, weakness, and fatigue, six months of abdominal swelling and two months of peripheral edema. Repeated abdominal paracenteses had been necessary during the several months prior to admission. On examination she was poorly nourished and slightly icteric with palmar erythema and sparse axillary and pubic hair. Multiple small spider angiomata were present. The abdomen was markedly enlarged and a fluid was present. No organs were palpable. The extremities showed marked peripheral edema. Laboratory studies included a red blood count of 3.7 millions with $11.7 \mathrm{Gm}$. of hemoglobin; urine urobilinogen was positive in dilution of $1-20$; serum bilirubin 1.6 milligrams per cent; bromsulfalein retention 64 per cent in 30 minutes. Serum albumin $2.0 \mathrm{Gm}$. per cent, globulin 3.7 Gm. per cent. Blood urea nitrogen $8 \mathrm{mg}$. per cent. Hepatic and splenic artery ligation was carried out on December 31, 1952. Microscopic examinations of liver tissue obtained at that time showed a marked portal 
cirrhosis with complete distortion of normal lobular pattern. There was marked increase in connective tissue which divided the liver into small nodules. There was some evidence of regeneration and there were slight fatty changes. There was also evidence of regressive change in some liver cells.

TIBB (P.H.): A 43-year old woman with known cirrhosis who had had a splenectomy and spleno-renal anastomosis in July, 1948. She was admitted to the Presbyterian Hospital for the fourth time on March 11, 1953 because of persistent bleeding of the esophageal varices. No history of alcoholism or hepatitis. Physical examination was not remarkable. Laboratory studies included a normal prothrombin time, a serum bilirubin of $0.8 \mathrm{mg}$. per cent, serum albumin $4.1 \mathrm{Gm}$. per cent, globulin $2.7 \mathrm{Gm}$. per cent. Bromsulfalein retention 51 per cent in 30 minutes; alkaline phosphatase 9.9 Bodansky units. Porto-caval anastomosis was carried out on April 7, 1953. Examination of liver tissue obtained at that time showed rather poor preservation of histologic detail but distinct evidence of well-established cirrhosis, the architecture giving the impression of a somewhat long-standing process. It was difficult to evaluate the state of regenerative activity.

CHEF (P.H.) : A 42-year old male with a history of jaundice three years prior to admission and development of abdominal enlargement shortly after this event. On medical therapy at that time, jaundice and ascites gradually cleared but abdominal fluid recurred one year prior to admission and required a paracentesis every two months. Physical examination was striking only in the presence of a markedly distended abdomen with a fluid wave. The liver and spleen were not palpable. Significant laboratory studies included a prothrombin time of 17.5 seconds, serum bilirubin $1.7 \mathrm{mg}$. per cent, serum albumin $3.9 \mathrm{Gm}$. per cent, globulin $2.2 \mathrm{Gm}$. per cent; cephalin flocculation and thymol turbidity negative; alkaline phosphatase 7.5 Bodansky units; bromsulfalein retention 24 per cent in 30 minutes. The patient was subjected to abdominal laparotomy on March 31, 1953. Examination of liver obtained at that time showed an active phase of portal cirrhosis with some sections showing more recently established changes, others of longer duration.

PFEI (P.H.): A 60-year old alcoholic male with a three-year history of ascites and the onset of hematemesis three months prior to admission. On examination the liver was palpable three finger breadths below the costal margin and the spleen was also palpable. There was a small amount of fluid in the abdomen. Significant laboratory studies included a prothrombin time of 16.9 seconds; cephalin flocculation 3 plus, thymol turbidity 3 plus; serum bilirubin $0.2 \mathrm{mg}$. per cent; serum albumin $3.5 \mathrm{Gm}$. per cent, globulin $2.7 \mathrm{Gm}$. per cent; bromsulfalein retention 35 per cent in 30 minutes. A porto-caval anastomosis was accomplished on January 6, 1953. Liver tissue obtained at that time showed an advanced state of cirrhosis in an active phase. There was complete separation of liver parenchyma into pseudolobules with considerable regression and regenerative change in the liver cells.
Marked prominence of small bile ducts and inflammatory cells in the fibrotic portal tissue.

$B E C K$ (P.H.) : A 48-year old alcoholic male with recurrent episodes of ascites for three years. The abdominal fluid had been sufficient in amount to require paracenteses every two weeks for the year prior to operation. On examination the abdomen was markedly enlarged but the liver was palpable four finger breadths below the costal margin. No peripheral edema was present. Significant laboratory studies included a negative cephalin flocculation and negative thymol turbidity. Serum albumin $3.7 \mathrm{Gm}$. per cent, globulin $2.4 \mathrm{Gm}$. per cent, serum bilirubin $1.3 \mathrm{mg}$. per cent; prothrombin time 21 seconds, bromsulfalein retention 7 per cent in thirty minutes; alkaline phosphatase 4.4 Bodansky units. A porto-caval shunt was accomplished on January 13, 1953. The liver tissue obtained at that time showed a well established cirrhosis with evidence of moderate activity. There was minimal proliferation of bile ducts and the liver parenchyma showed considerable preservation. Some retention of bile within the ducts and canaliculi.

LUST (P.H.) : A 55-year old male with no significant symptoms until the sudden onset of severe hematemesis which led to his admission. There was no history of peripheral edema or ascites. On examination the only remarkable finding was an enlarged liver three finger breadths below the costal margin. The spleen was not palpable and no free abdominal fluid could be demonstrated. Significant laboratory studies included a prothrombin time of 17.5 seconds, alkaline phosphatase 5.6 Bodansky units; serum albumin $3.5 \mathrm{Gm}$. per cent, globulin $2.2 \mathrm{Gm}$. per cent, serum bilirubin $0.8 \mathrm{mg}$. per cent, bromsulfalein retention 22 per cent in 30 minutes : cephalin flocculation 1 plus, thymol turbidity 1 plus. A portocaval shunt was accomplished on January 20, 1953 at which time $500 \mathrm{cc}$. of ascitic fluid was found. Liver tissue obtained at this time showed quite severe irregular distortion of the liver architecture by an active cirrhotic process with a considerable element of fatty metamorphosis still present. Signs of regenerative activity were quite prominent.

\section{REFERENCES}

1. Heller, H., and Urban, F. F., The fate of the antidiuretic principle of postpituitary extracts in vivo and in vitro. J. Physiol., 1935, 85, 502.

2. Eversole, W. J., Birnie, J. H., and Gaunt, R., Inactivation of posterior pituitary antidiuretic hormone by the liver. Endocrinology, 1949, 45, 378.

3. Birnie, J. H., Inactivation of posterior pituitary antidiuretic hormone by liver extracts. Federation Proc., 1950, 9, 12.

4. Ralli, E. P., Robson, J. S., Clarke, D., and Hoagland, C. L., Factors influencing ascites in patients with cirrhosis of the liver. J. Clin. Invest., 1945, 24, 316.

5. Hall, C. A., Frame, B., and Drill, V. A., Renal excretion of water and antidiuretic substances in patients with hepatic cirrhosis and rats with dietary liver injury. Endocrinology, 1949, 44, 76. 
6. Lloyd, C. W., and Lobotsky, J., Serum antidiuretic substances and urinary corticosteroid in the human. J. Clin. Endocrinol., 1950, 10, 318.

7. Fremont-Smith, F., The mechanism of edema formation. New England J. Med., 1932, 206, 1286.

8. Adlersberg, D., and Fox, C. L., Jr., Changes of the water tolerance test in hepatic disease. Ann. Int. Med., 1943, 19, 642.

9. Labby, D. H., and Hoagland, C. L., Water storage and the movements of body fluids and chlorides during acute liver disease. J. Clin. Invest., 1947, 26, 343.

10. Van Dyke, H. B., Ames, R. G., and Plough, I. C., The excretion of antidiuretic hormone in the urine of patients with cirrhosis of the liver. Tr. A. Am. Physicians, 1950, 63, 35.

11. White, A. G., Rubin, G., and Leiter, L., Studies in edema. III. The effect of Pitressin on the renal excretion of water and electrolytes in patients with and without liver disease. J. Clin. Invest., 1951, 30, 1287.

12. Nelson, W. P., III, and Welt, L. G., The effects of Pitressin on the metabolism and excretion of water and electrolytes in normal subjects and patients with cirrhosis and ascites. J. Clin. Invest., 1952, 31, 392.

13. Miller, G. E., Water and electrolyte metabolism in congestive heart failure. Circulation, 1951, 4, 270.

14. Miller, G. E., The role of water and salt in the development of heart failure. New York State J. Med., 1951, 51, 1725.

15. Shorr, E., Baez, S., Zweifach, B. W., Payne, M. A., Mazur, A., and Metz, D. B., The antidiuretic action of the hepatic vasodepressor ferritin (VDM) and its occurrence in conditions associated with antidiuresis in man. Tr. A. Am. Physicians, 1950, 63, 39. 